\title{
The Ottawa Field-Naturalists' Club Awards for 2010, Presented April 2011
}

\author{
Ken Allison, Irwin Brodo, Julia Cipriani, Christine Hanrahan and Eleanor Zurbrigg
}

On April 16 $6^{\text {th }}, 2011$ members and friends of the Ottawa Field-Naturalists' Club gathered at the Club's Annual Soirée at St. Basil's Church in Ottawa. Awards were given to members and non-members who distinguished themselves by accomplishments in the field of natural history and conservation, or by extraordinary

\section{Ronald E. Bedford - Honorary Member}

After 32 years of committed service to the Ottawa Field-Naturalists' Club's (OFNC) Publications Committee, Ron Bedford has stepped down as Chair. His humour, steady hand, sharp eye, sound judgement and grasp of the committee's function will be missed.

The Publications Committee is responsible for the policies and production of the Club's two quarterly publications, The Canadian Field-Naturalist and Trail \& Landscape, along with special issues of these publications.

The dominant quarterly publication is The Canadian Field-Naturalist (CFN), a scientific journal recognized internationally, has been the major project for the Club for over one hundred and twenty-five years. In overseeing the CFN, Ron worked closely with Francis Cook, its long-standing editor, and the late Bill Cody, business manager. Issues of editorial policy and publication format were addressed. The latest challenge has been to produce an online version of the journal.

Ron played an important role in establishing the OFNC Publication Policy in the early 1980s. As one member described it, the policy was as important as it was contentious at the time. The policy stands today essentially as it was developed almost 30 years ago.

\section{Daniel F. Brunton - Honorary Member}

Ask anyone in the Ottawa region to name a prominent and respected naturalist, and if they know of anyone that might fit that description, they are most likely to name Dan Brunton. He is the expert that is most frequently consulted by the local media in matters of natural history, and municipal and regional departments in the Ottawa region often call on his help and opinion for environmental issues.

All this is not surprising if one looks at Dan's remarkable achievements over the past 40 years. Although counting himself as principally a botanist and birder, he has publications on moles, wolves, turtles and salamanders as well. His major scientific work has dealt with quillworts (Isoetes) and ferns in general, usually coauthored with Donald Britton of Guelph University. This activity within the Club. In particular, long time service to the Club's publications, lifetime study of birds and their songs, forest stewardship efforts and teaching of natural history to youth are all in evidence among this year's winners. The following citations for those who received an award were read to the members and guests assembled for the event.

Ron's calm, thoughtful, professional input throughout was a huge help in keeping the participants focused and getting the job done. The core elements of the policy are intact and still serve the OFNC and its publications very well in their contribution to the larger community in Ottawa and across Canada. This is a testament to the success of Ron's contributions.

As Committee Chair, Ron supported and encouraged the acceptance of numerous special contributions proposed and subsequently published in the CFN. Among them are Irwin Brodo's "Lichens of the Ottawa Region, Second Edition"; Joyce and Allan Reddoch's "The Orchids in the Ottawa District"; John L. CranmerByng's "A Life with Birds: A Biography of Percy Algernon Taverner 1875-1947"; and Alexander Burnett's "A Passion for Wildlife: A History of the Canadian Wildlife Service".

Ron is also a keen bird watcher and often goes on the Club bus trip to Point Pelee. With his wife Trudy, he led many nature walks in the eastern part of the city.

For his commitment and stewardship, the Club is proud to offer an Honorary Membership to Ron Bedford.

has resulted in more than 30 peer-reviewed publications including the description of over 15 new North American taxa. Dan, however, is an expert general botanist with a broad knowledge of plants of every kind. He also has a long list of publications on birds, most of them in Trail \& Landscape, The Canadian Field-Naturalist (CFN) or Blue Jay.

Dan was born and raised in Ottawa and spent his formative years first with a passion for astronomy, and then birding, often in the company of folks like Ron Pittaway, Monty Brigham, Joe Dafoe and Ken Ross. $\mathrm{He}$ received his university degree in Geography and Botany from Carleton University in 1973. Dan worked for several years as a park naturalist, especially in Algonquin Park, and he has always been very active 
in that park and its biota. Dan also worked in Alberta at the Kananaskis Provincial Park, helping to develop their interpretation program.

Dan Brunton has operated a private consulting firm (Brunton Consulting Services) since the 1970s, doing environmental assessments, botanical or biological surveys, or providing expertise to governmental agencies. He has naturally become very much interested in conservation matters and has served the community well in this regard. Dan received the Ottawa Field-Naturalists' Club's 2003 Conservation Award for his work is establishing a Riverkeeper program in Ottawa. The Transportation Association of Canada awarded him their 1999 Environmental Achievement Award, and, in 1992, he received the Canada 125 Medal from the Canadian Government for his contributions to natural features protection and conservation in the National Capital Region. Dan received the Club's Anne Hanes Natural History Award in 1988 for his book, Nature and Natural Areas in Canada's Capital.

\section{Michael D. Cadman - Honorary Member}

Mike Cadman is a Songbird Biologist with the Ontario Region of the Canadian Wildlife Service (CWS), Environment Canada.

Mike has been studying birds for most of his life, and earned his MSc from the University of Toronto for research on American Oystercatchers. Mike is best known as the coordinator and lead editor of both the first and second versions of the Atlas of the Breeding Birds of Ontario, published in 1987 and 2007, respectively. These were both major projects, involving five years of field work by many hundreds of volunteers, covering the entire province. The 2007 Atlas is the largest and most comprehensive wildlife study in Ontario's history. Having the two atlases 20 years apart allows scientists to compare the two datasets and track changes in bird distribution and abundance.

In addition to the two atlas projects, Mike has been involved in many bird monitoring programs in Ontario. These have included the Forest Bird Monitoring Program and the Eastern Loggerhead Shrike Recovery

\section{Francis R. Cook - Member of the Year}

The OFNC Member of the Year Award recognizes the member judged to have contributed the most to the Club in the previous year. Francis Cook is the 2010 Member of the Year for his exceptional effort to bring The Canadian Field-Naturalist (CFN) up to date.

Francis Cook was Editor of the CFN from 1962 to 1967 and served as an Associate Editor (herpetology) for several years thereafter. In 1981 he returned as Editor of the CFN. During this past thirty-year span he has maintained the $\mathrm{CFN}$ as the most scientifically important and visible aspect of the Club. This has been
The Ottawa Field-Naturalists' Club (OFNC) has benefited tremendously from Dan's interest and activity in Club affairs ever since he joined in 1967. He has served on numerous committees and chaired many including the Awards Committee (see his interesting article in Trail \& Landscape 21(5): 236-243, 1987), and was President of the Club from 1982-1983. He received the George McGee Service Award for 1985. Dan contributed dozens of articles to Trail \& Landscape and, in 2004, prepared a detailed and fascinating history of the Club in The Canadian Field-Naturalist (vol. 118: 134). In fact, Dan provides a unique contribution to the OFNC as the Club historian, and he shares this knowledge freely.

For his achievements as a knowledgeable naturalist, accomplished botanist and birder, important environmentalist, outstanding service to the Club, and spokesperson for natural history in the National Capital Region, the Club is proud to offer Honorary Membership to Daniel F. Brunton.

Team. He also initiated and coordinated the Ontario Rare Breeding Bird Program which resulted in the publication of Ontario Birds at Risk. He helped develop Bird Studies Canada's Marsh Monitoring Program. He coordinates Wildlife Watchers, which encourages volunteer participation in wildlife monitoring projects, and he organizes the Guelph Christmas Bird Count.

Mike also contributes to the conservation of birds and their habitats by serving with organizations such as the Society of Canadian Ornithologists, Birds Studies Canada, Environment Canada's national landbird committee and the Ontario Partners in Flight Working Group. In the past, he has chaired National Recovery Teams for Eastern Loggerhead Shrike, Acadian Flycatcher, Hooded Warbler, and Henslow's Sparrow.

The Ottawa Field-Naturalists' Club would like to recognize Mike's significant contributions to the understanding of birds, bird distributions, and habitat requirements by making him an Honorary Member.

marked by his receiving during this period three external awards for his and the journal's excellence.

It is, however, for his recent effort to bring the CFN back on schedule that Francis Cook is being recognized as Member of the Year for 2010. For various reasons, during recent years the publication schedule slipped badly. Looking ahead to retirement with the completion of the 2010 Volume 124, and with the intention of the OFNC to begin an online edition of the CFN in 2011 under a new Editor, Francis undertook the demanding task of completing the outstanding issues. 
This meant producing seven issues within about ten months. Volume 123(2) appeared in November 2010 (the fourth issue to be published in 2010), from which he determined that he could expedite matters by preparing the remaining six in tandem rather than sequentially. Of these, Volume 123(3) appeared in February 2011 and Volume 123(4) in mid-March; the remaining four issues are targeted to appear this Spring. This constitutes a production level never attempted before, let alone achieved in the 130 year history of the journal.

For these reasons, and in recognition of these unique achievements, it is our pleasure to present Francis Cook with the Member of the Year Award for 2010.

\section{Barbara Gaertner and Diane Kitching - George McGee Service Award}

The George McGee Service Award is given in recognition of members who have contributed significantly to the smooth running of the Club over several years.

Barbara Gaertner and Diane Kitching are excellent choices for this award, recognizing their years of hard work, reliability and dedication as volunteer leaders for the Macoun Field Club. This is the nature club for youngsters in grades 4 through 12 that is sponsored by the OFNC and the Canadian Museum of Nature. Barbara's and Diane's contributions, supporting and assisting Rob Lee, have been critical to the success of the club and its operations.

Over the years, Barbara and Diane have shared some responsibilities and alternated others. Both attend most of the young naturalists' indoor meetings, give talks at the indoor meetings, come on nearly all the field trips and sometimes lead a sub-group, deal with parents when new youth come in, act as the contact person for new members, make sure all members are properly registered, and find speakers for the indoor meetings. They have represented the Macoun Field Club at public venues such as the Wildlife Festival display at Billings Bridge. Both have been, and Diane currently is, the Macoun Field Club representative on the OFNC Council. They also have their own study trees and write about them for the Little Bear - the annual publication - thereby encouraging the young naturalists to do the same. Coincidentally, both of their study trees were later killed by lightning. Barbara and Diane have become better naturalists after all these years as leaders for the Macoun Field Club and are very valuable people to the group.

Barbara proofreads the Macoun web page, goes on camping trips, prints out a customized trip list of youth attending field trips, and takes field notes on field trips to the Study Area.

Diane is the contact person for calls from parents wanting field trip information (every two weeks), and she makes carpooling arrangements and ensures kids are properly dressed. And even if Diane didn't go on a camping trip, she would supply the now famous cream of chicken soup! For a time, Diane produced the monthly newsletter when there was no young person to do this. She also provides art supplies for drawing workshops.

Barbara and Diane have provided very valuable service to the Macoun Field Club, and therefore to the Ottawa Field-Naturalists' Club, and we are pleased to recognize this service through the 2010 George McGee Service Award.

\section{Limerick Forest Advisory Committee, Friends of Limerick Forest, Grenville Land Stewardship Council, and the United Counties of Leeds and Grenville - Conservation Award (Non-member)}

The Conservation Award for a non-member is given in recognition of an outstanding contribution by a nonmember in the cause of natural history conservation in the Ottawa Valley, with particular emphasis on activities within the Ottawa District.

The 2010 award recognizes the work of four groups who have worked together successfully to ensure ecologically sustainable stewardship for the Limerick Forest. These four are the Grenville Land Stewardship Council, the Limerick Forest Advisory Committee, the Friends of Limerick Forest and the United Counties of Leeds and Grenville.

The Limerick Forest is a large, 5,782 hectare tract in the United Counties of Leeds and Grenville (UCLG). It contains provincially significant wetlands and is home to several species of at risk flora and fauna. In 2001, the Grenville Land Stewardship Council (GLSC) (which has recently been incorporated into the new Leeds and Grenville Stewardship Council) set up the Limerick Forest Advisory Committee (LFAC). LFAC and the Stewardship Council worked closely with the UCLG during the transition of responsibility for the forest from the province to the county. At this time, there were no permanent staff to oversee the forest.

The LFAC, an entirely volunteer run organization, proved invaluable. Members dedicated countless hours to preparing a Long Range Strategic Plan and Terms of Reference to guide forest management in an ecologically sustainable direction. They also chaired subcommittees (including an ecology sub-committee), performed on-the-ground work (clearing trails, removing garbage, etc.), supervised volunteer days, monitored invasive species, and undertook wildlife enhancement projects. The feeling was, and is, that Limerick is very much a community forest. Therefore, recreational opportunities were promoted, and parking areas, picnic sites and trails were developed or repaired, and the forest headquarters were fixed up. Detailed maps of the forest were also prepared. Open houses were well attended. Participants enjoyed guided walks, displays, 
horse-drawn wagon rides, and barbeques. Brochures about Limerick were later produced, and a website was set up, all with the aim of promoting the forest as a community resource to be used wisely, cherished, and protected.

The UCLG hired a consultant to prepare a Twentyyear Forest Management Plan, which a sub-committee of LFAC reviewed and offered comments on. Such collaboration is typical of the cooperative efforts that characterize the relationship between volunteers and the United Counties of Leeds and Grenville.

More recently, the LFAC was dissolved, to be replaced by the Friends of Limerick Forest. Many of the same long-serving volunteers are active on this new committee, which carries on the tradition of committed volunteer work and cooperation with the UCLG to enhance and maintain Limerick Forest.

The work performed by volunteers, the County and the Grenville Land Stewardship Council is remarkable. It is truly thanks to all of them that the Limerick Forest today is a fine example of what an ecologically sustainable forest can and should be. For all these reasons and more, these four organizations are worthy recipients of the Conservation Award (Non-member) for 2010. Congratulations!

\section{Monty Brigham - Anne Hanes Natural History Award}

The Anne Hanes Natural History Award recognizes excellence in natural history research by an amateur. This year the award goes to Monty Brigham for his work over many decades recording the sounds of Canadian bird species.

Monty is one of Canada's foremost experts on audio recording and identification of bird sounds. His recordings are widely recognized for their quality and quantity. He has recorded the songs and calls of over 300 Canadian bird species. He has published a number of collections of Canadian nature sounds, starting with "Songs of the Seasons", produced in 1979 to help commemorate the OFNC's centennial year. He has also prepared "Pelee Spring" (1980) and "Algonquin Park" (1981) and "Natural Sounds of Ontario: Birds, Frogs and Mammals" (2003). In the early 1990's he produced
"Bird Sounds of Canada", a set of six CD's designed to complement "Birds of Canada".

At present, many of Monty's recordings are available online as he has been a major contributor of sound recordings to Dendroica, an interactive website with vocalizations and images of birds from Canada, USA, and Mexico. This website is sponsored by Environment Canada and the United States Geological Survey, among others.

For his outstanding contribution to our knowledge of bird, mammal and amphibian vocalizations in Eastern Ontario and across Canada, the Ottawa FieldNaturalists' Club is very pleased to present Monty Brigham with the Anne Hanes Natural History Award for 2010 .

\section{MacSkimming Outdoor Education Centre - Mary Stuart Education Award}

In these days of trimmed School Board budgets and cancelled enhancement programs in our schools, it is reassuring to know that there are places like the MacSkimming Outdoor Education Centre. This facility, funded and staffed by the Ottawa-Carleton District School Board, has provided Ottawa school children from Kindergarten to Grade 12 with quality education in natural history and outdoor skills since 1967. There are four permanent staff teachers who run outdoor classes. About 23,000 students visit the Centre each year, spending anywhere from a few hours to four days, learning about nature.

Although the Centre is a low-profile affair, their work has not gone unnoticed. It recently received the prestigious Award for Excellence in Environmental Education from the Canadian Network for Environmental Education and Communication (EECOM). They noted that many former students say that their lives were changed by their experiences at the Centre, either by encouraging them to choose a career in environmental related fields, or simply by showing them how to become a more environmentally responsible citizen.

The MacSkimming Outdoor Centre is located in Cumberland, on 425 acres of forests, fields and wetlands, with boardwalks to take the students close to the action. In 1969, 254 acres of this property were designated as the Beckett's Creek Migratory Bird Sanctuary by Environment Canada. The children learn about the weather, how to identify trees, what's living in the water, plants and soils, animals in the forest and their interactions, and much more. Among the goals of the program are: increasing knowledge about nature and natural processes, increasing environmental literacy, getting comfortable in the outdoors and simply enjoying the joys of the natural world.

For their many years of exceptional service in teaching natural history to Ottawa area children, the OFNC is proud to present the MacSkimming Outdoor Education Centre and its Site Program Administrator, Kevin Wallace, with the Mary Stuart Education Award for 2010 . 